\title{
CONCEPT OLD AGE IN ENGLISH: COGNITIVE-SEMANTIC ANALYSIS
}

\section{Holyk S. V.}

\section{INTRODUCTION}

Present-day developments in the fields of medicine, genetics and biomedical technologies have influenced the increase in the lifespan and older people live longer and healthier than even 50 years ago. Therefore, the problem of population ageing is gaining importance and becomes the object of interdisciplinary study.

Old age as a social phenomenon is usually defined through the prism of its medico-biological and socio-philosophical characteristics as a final stage of human life with considerable physiological and psychological changes leading to little involvement of a person in social activities ${ }^{1}$.

This research adopts a cognitive-semantic approach when meaning is defined as conceptualization. It aims at revealing the notional content of concept OLD AGE in English with the focus on the definitions of the lexeme old age in present-day lexicographical sources (both printed and on-line). Firstly, the concept of OLD AGE as a mental unit, complex knowledge cluster is analysed and its nominative field is defined. The research proves that the key lexeme old age proves to have a multicomponent semantic structure representing the period or time in life when one is old and the state or condition of being old. In the majority of studies, the nominative field of the concept is viewed as heterogeneous and consists of the nucleus and periphery. The nominative field is verbalized by direct nominative units encoding the concept and making up its nucleus, as well as nominations of separate cognitive features disclosing both the content of the concept and attitudes to it in different communicative situations (the periphery) ${ }^{2}$. Furthermore, the present study provides the cognitive-semantic analysis of synonyms to the key lexeme old age, chosen as the name of the concept.

Present-day cognitive linguists have repeatedly emphasized that the concept as an object of research requires a multidimensional methodological

\footnotetext{
${ }^{1}$ Чаграк Н. І. Соціальні теорії старіння і старості у контексті освітньої геронтології. Теоретичні питання культури, освіти та виховання : зб. наук. праць Київського національного лінгвістичного університету. 2015. № 52. С. 154-160.

2 Попова 3. Д. Когнитивная лингвистика / 3. Д. Попова, И. А. Стернин. М. : АСТ : Восток-Запад, 2007. С. 68.
} 
approach. Pimenova believes that "the concept is disseminated in the lingual signs used to verbalize it. In order to reconstruct the concept's structure, one needs to study the entire verbal corpus encoding it, i.e. lexical units, idioms, paroemias etc. ${ }^{3}$ V.Evans states that cognitive model profile is an important construct in LCCM theory (The Theory of Lexical Concepts and Cognitive Models), and it is essential to providing an account of meaning construction. ${ }^{4}$ Moreover, Evans adds that "a cognitive model is a coherent body of multimodal knowledge directly grounded in the brain's modal systems, and derives from the full range of experience types processed by the brain including sensory-motor experience, proprioception and subjective experience including affect" 5 .

\section{The Nominative Field of the Concept: the Methodology of the Research}

It is common knowledge that language is one of the basic tools of cognition and conceptualization. This means that the concept can be encoded with lingual units.

Conceptualization, being a process of human cognition, aims at capturing the content of concepts, while the concept description refers to special research procedures, including definitional, componential, contextual and etymological analyses. The composition of any concept can be revealed through dictionary definitions of lingual units used to represent it, as well as in speech contexts.

The analysis of lingual means contributes to the identification of concept's main cognitive features, the description of its content, and modelling its structure. In linguistics, there seems to be a tendency to believe that the concept is encoded with the help of the word, although the analysis at the word level reveals the most important cognitive features, but only partially. Accordingly, the analysis of concept's verbalization should be conducted at the levels of words, phrases, idioms, sentences, texts, and even non-verbal means ${ }^{6}$.

An important stage in performing the conceptual analysis is the identification of the concept's nominative field, usually based on the

3 Пименова М.В. Предисловие. //Введение в когнитивную лингвистику. Кемерово, 2004. C. 9.

${ }^{4}$ Evans V. What's in a concept? Analog versus parametric concepts in LCCM Theory. // The Conceptual Mind: New Directions in the Study of Concepts, MIT Press, 2015. P. 277.

${ }^{5}$ Evans V. Conceptual vs. Inter-lexical polysemy. An LCCM Theory Approach.// Language Learning, Discourse and Cognition: Studies in the tradition of Andrea Tyler. Eds. Pickering L., Evans V. John Benjamins Publishing House, 2018. P. 167.

${ }^{6}$ Єсипенко Н. Г. Текстові концепти та методи їх аналізу. // Вісник Волинського національного університету імені Л. Українки. Мовознавство. Луцьк : ВНУ, 2009. Вип. 5. С. 253. 
analysis of lexicographical sources. The nominative field, according to Popova \& Sternin, is defined as "a set of lingual means which express the concept at a particular time period in society and are represented by different parts of speech"7. Sternin is the first to describe the structure of the nominative field as a two-component unity with its nucleus and periphery. However, in this research the idea of nominative field subdivision into the three constituent parts (nucleus, medial zone and periphery) is applied. The notional content of the nucleus is made up of the set of sememes representing the key lexemes of the concept. Cognitive scientists state that seme analysis provides a link to the ideal sphere in language and, thus, we reveal the content of concepts and objectify their verbalization ${ }^{8}$. It is the word semantics that principally displays conceptual features. Therefore, in their studies of concepts the majority of linguists proceed from the meaning of the lingual sign to the content of the corresponding concept ${ }^{9}$. Kolegaeva assumes that the use of dictionary entries facilitates the identification of smaller lingual units, such as definitional features. These are said to be the smallest autonomous verbal constituents of the nominative field ${ }^{10}$.

In order to study concept's verbal expression, the researcher should start with the analysis of its name (or in other terminology key lexeme), followed by the analysis of its meanings. The study of dictionary definitions, said to commonly index and catalogue the language means of concept's expression, provides the researcher with the systemic choice of lexical material for further analysis.

Evans believes that "it stands to reason that representations in the linguistic system - semantic structure - is qualitatively distinct from representations in the conceptual system - conceptual structure". "From the present perspective, the linguist concludes, words are in fact cues that index or point to body-based states processed and stored by the brain"11.

Describing the stages in constructing the nominative field of any verbalized concept, cognitive linguists assume that the selection of

${ }^{7}$ Попова 3. Д. Когнитивная лингвистика / 3. Д. Попова, И. А. Стернин. М. : АСТ : Восток-Запад, 2007. С. 66.

${ }^{8}$ Бабушкин А.П. Концепты разных типов в лексике и фразеологии и методика их выявления. // Методологические проблемы когнитивной лингвистики. Воронеж: Изд-во Воронеж, гос. ун-та, 2001. С. 52.

${ }^{9}$ Алефиренко Н. Ф. Современные проблемы науки о языке: Учебное пособие. М. : Флинта: Наука, 2005. С. 183.

${ }^{10}$ Колегаєва I.M. Конструювання номінативного поля концепту: етапи та одиниці . // Записки з романо-германської філології. 2018. N 1(40). С. 122.

${ }^{11}$ Evans V. Conceptual vs. Inter-lexical polysemy. An LCCM Theory Approach // Language Learning, Discourse and Cognition: Studies in the tradition of Andrea Tyler. Eds. Pickering L., Evans V. John Benjamins Publishing House, 2018. P. 163. 
nominative units (such as, sememes together with their defenitions, collocations and phraseological units and paroemias) semantically related to the name of the concept from lexicographical sources is the first step in the research. Another stage is the definitional analysis that aims at identifying key semes which can have different definitional features in several lexicographical sources ${ }^{12}$. Similar to this idea, Nikitin specifies: "The seme is an unnominated part of the meaning"13. It is expressed via definitional features selected from dictionary entries of corresponding lexical units. The seme, being a non-material, purely semantic element, is materialized in the form of definitional features, indexed in dictionary entries. ${ }^{14}$ In addition, researchers claim that "the arrangement of key lexemes as to their notional potential provides the material of "WHAT is named, HOW it is characterized and WHAT types of transformations are observed within the field under research" 15 .

Thus, the study of concepts via language proves to be the most reliable method of linguistic analysis which helps to define conceptual features and present the concept's structure. The analysis starts with the selection of lingual units encoding the concept, and proceeds with their dictionary definitions and dicourses. The semantic features, defined in the course of the research into the meanings within the units of the nominative field, are commonly referred to as cognitive features of the concept.

\section{Definitional Analysis of the Lexeme Old Age}

The nucleus of the nominative field of the concept OLD AGE is formed by the sememes of the noun old age, which is used as the concept's name to encode it. The medial zone is represented by the derivatives of the key lexeme old age, its synonyms and free word combinations. Bound word combinations (or idioms) and paroemias constitute the periphery.

The first stage of our research is the definitional analysis which belongs to traditional methods of semantic analysis. Its main objective is to disclose the notional content of the concept as an abstract constituent through the analysis of meanings of the concept's name as indexed in different lexicographical sources.

\footnotetext{
12 Колегаєва I.M. Конструювання номінативного поля концепту: етапи та одиниці // Записки з романо-германської філології. 2018. № 1(40). С. 125.

${ }^{13}$ Никитин М. В. Курс лингвистической семантики. Санкт-Петербург: Научный центр проблем диалога, 1996. С.117.

${ }^{14}$ Смаглій В. М. Ядро номінативного поля концепту LANGUAGE. Вчені записки ТНУ імені В. І. Вернадського. Серія: Філологія. Соціальні комунікації. Том 30 (69). № 2. Ч. 1. 2019. C. 119.

${ }^{15}$ Колегаєва I.M. Конструювання номінативного поля концепту: етапи та одиниці // Записки з романо-германської філології. 2018. № 1(40). С. 126.
} 
The study of dictionary definitions, which commonly register lingual means used to represent the concept, helps to systematically select the lexical material for further research, because "despite all the weaknesses in the lexicographical procedure of defining semantic components, it still remains one of the easiest and most effective methodologies of componential analysis" ${ }^{\prime 6}$. In semasiology, dictionary definitions have been used as the source of defining word semantic components since the theoretical works by Arnold, Karaulov, Levytskii and many others. However, in terms of Sternin, dictionary definitions are not build according to the seme principle, their components require further interpretation and reformulation into the format of semes ${ }^{17}$. In this sense, he adds that preliminary generalization of dictionary definitions selected from different lexicographical sources might be an important prerequisite for further definitional analysis aimed at defining the semes. This procedure is important, since different definitions complement one another and add to the list of word meanings, as well as semantic components making up these meaning.

Moreover, dictionary definitions appear to be a sufficient and objective material to encode the structure of the word meaning. Different dictionaries provide different, both in their character and structure, definitions. According to Kubriakova, "the definitional analysis of the word and defining the structure of knowledge represented in it, as well as the conceptual analysis seem to be partially interrelated, although they represent different levels of analysis. The dictionary aims at providing such a definition that will identify the word both in the text and in discourse; cognitive analysis presents a wider scope of meanings of the nominated object and reflects knowledge necessary for understanding the object by speakers with different educational backgrounds. Usually, this knowledge is shared by a certain community. Whereas the conceptual analysis pursues the aim to define the conceptual structure which is verbalized and substantiate its verbalization” 18 .

In this chapter, I provide the analysis of the semantic structure of the key lexeme representing the concept OLD AGE. It is the noun old age, which meets the requirements for defining the name of the concept, according to Popova and Sternin, because it is a common noun, stylistically neutral, fully nominates the concept and gives material for its cognitive interpretation ${ }^{19}$. The semantic structure of the lexeme old age is

${ }^{16}$ Левицкий В.В. Семасиология. Винница: Нова книгаю 2006. С. 91.

${ }^{17}$ Стернин И. А. Методы описания семантики слова. Ярославль: Истоки, 2013.

${ }^{18}$ Кубрякова Е. С. К определению понятия имиджа / Е. С. Кубрякова // Вопросы когнитивной лингвистики. 2008. № 1. С. 8.

${ }^{19}$ Попова 3. Д. Когнитивная лингвистика / 3. Д. Попова, И. А. Стернин. М. : АСТ : Восток-Запад, 2007. С. 177-178. 
defined by selecting the sememes (or lexico-semantic variants) from dictionaries and this helps to designate the notional components of the concept OLD AGE. The definitions selected from 16 different English dictionaries and thesauri (both printed and electronic) provide the material for defining the most common meanings (sememes) forming the significatum of the concept OLD AGE. The algorithm of their compilation can vary in different dictionaries, i.e. certain meanings may occupy primary positions in dictionary entries, while, in some other sources, they could be secondary. However, what we aim at is describing the holistic picture, including the number and availability of sememes in each of the lexicographical sources under analysis.

The material of the research presents the selection from British and American dictionaries: I - Webster's New World Dictionary, II - Oxford Advanced Learner's Dictionary, III - Cambridge Dictionary Online, IV Collin's English Dictionary, V - Merriam Webster's Online Dictionary, VI Dictionary. Com, VII - MacMillan Online Dictionary, VIII - CoBuild, IX Free Dictionary, X - Oxford English Living Dictionary, XI - Urban Dictionary, XII - Wordsmyth Dictionary Online, XIII - Ultralingua, XIV Word Net Dictionary Online, XV - Your Dictionary, XVI - Longman Dictionary of Contemporary English. The research findings are shown in Table 1.

In cognitive linguistics, it is widely recognized that each sememe correlates with a particular cognitive domain. "This means that words do not represent neatly packaged bundles of meaning (the dictionary view), but serve as 'points of access' to vast repositories of knowledge relating to a particular concept or conceptual domain”, ${ }^{20}$ which proves Langacker's idea that word meanings correlate with particular cognitive structures ${ }^{21}$. Drawing on a study of Kubriakova, the meaning of a lexical unit can be regarded as " the concept captured in the word""22.

Accordingly, the analysis of dictionary definitions aims at defining those mental structures which correlate with the verbalization of the concept in native speakers' mentality. In cognitive semantics (e.g., Lakoff, Johnson, Langacker, Fillmore, Fauconnier), the meaning is usually defined as the conventional result of categorization and conceptualization processes by the representatives of certain ethnic or cultural groups. It is

\footnotetext{
${ }^{20}$ Evans V., Green M. Introduction to Cognitive Linguistics. / V. Evans, M. Green. N.Y.: Routledge, 2015. P. 160.

21 Langacker R. Foundations of Cognitive Grammar. Volume I. - Stanford: Stanford University Press, 1987. P. 99.

${ }^{22}$ Кубрякова Е. С. Язык и знание: на пути получения знаний о языке : части речи с когнитивной точки зрения. Роль языка в осознании мира : [монографія]. - М. : Язык славянской культуры. 2004. 555 с.
} 
also said to encode the experience, knowledge and feelings of people that, according to Selivanova, could contradict the reality ${ }^{23}$.

Our research results clearly demonstrate that the nucleus of the nominative field of the concept OLD AGE includes 20 sememes of the noun old age.

We proceed from the assumption that dominant meanings of the key lexeme are those which prove to be the most common in dictionary entries. The data shown in Table 1 indicate the most frequent sememes: [the time of life when one is old], [the (a) late (latter) time of life], [the period (stage) after 65], [decline of strength/health and vigor] (their usage is observed in 4 different dictionaries). These definitions might confirm the widespread idea that OLD AGE in English is viewed as the last stage or period in hum an life, usually after the age of 65 which is marked with the loss of strength (or decline) and serious health problems. According to the theory of prototypes by Rosch $(1973)^{24}$, these sememes could be regarded as prototype meanings that first come to mind when the noun old age is mentioned.

The sememes [advanced/-ing years] and [quality or state of being old/ older] proved to be less representative, although also meaningful for OLD AGE conceptualization. The data in Table 1 show that a number of different sememes, rather numerous, containing the bulk of information and characterizing OLD AGE among native speakers of English can be catalogued, but they are not frequently indexed in dictionary entries (found only in 2 out of 16 dictionaries), e.g., [the period in a person's life when one is old], [the period of your years towards the end of your life], [the last period of human life], [the later (latter) part of (normal) life], [quality or state of being towards the end of your life].

These examples suggest that OLD AGE can mostly be defined as a period in a human life, usually it is the last period, the end of the life cycle, which comes late or later in life (in comparison with another, obviously a younger period), it normally characterizes the stages of life and inevitably leads to death (or the end of life).

Also, the findings of this study reveal several unique sememes, i.e. those observed only in one of the lexicographical sources: e.g. [ideal time when you don't feel inhibited to say something embarrassing or outrageous because your days are numbered], [the part of your life when you are old], [the part after your prime], [the final stage of human life], [past middle age], [the fact of being old], [20 years older than you are], [no longer in good health].

\footnotetext{
${ }^{23}$ Селіванова О.О. Сучасна лінгвістика: термінологічна енциклопедія. Полтава : Довкілля-К, 2006. С. 305.

${ }^{24}$ Rosch E. Natural categories / E. Rosch // Cognitive Psychology. Elsevier, 1973. V. 7. P. 328-350.
} 


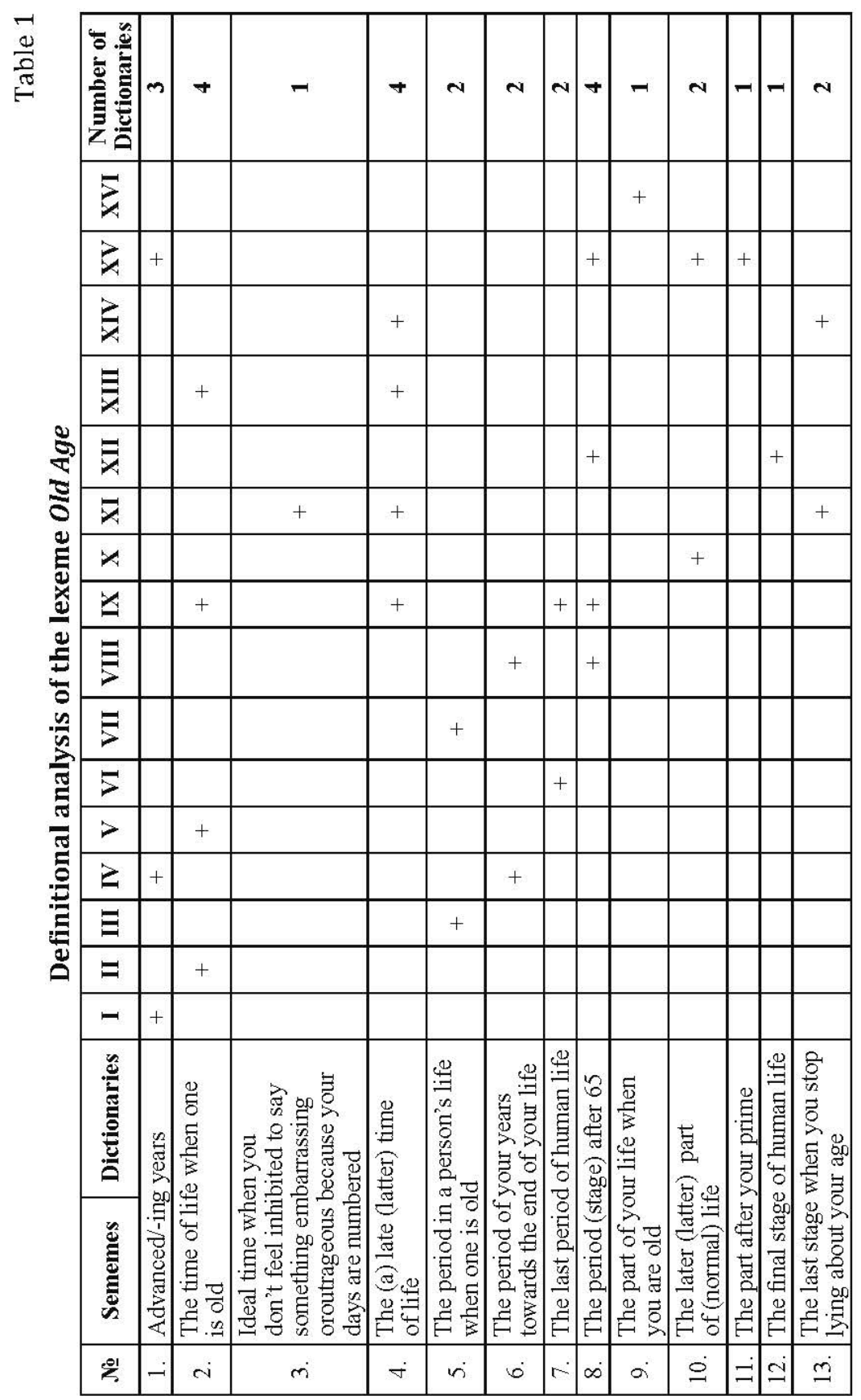




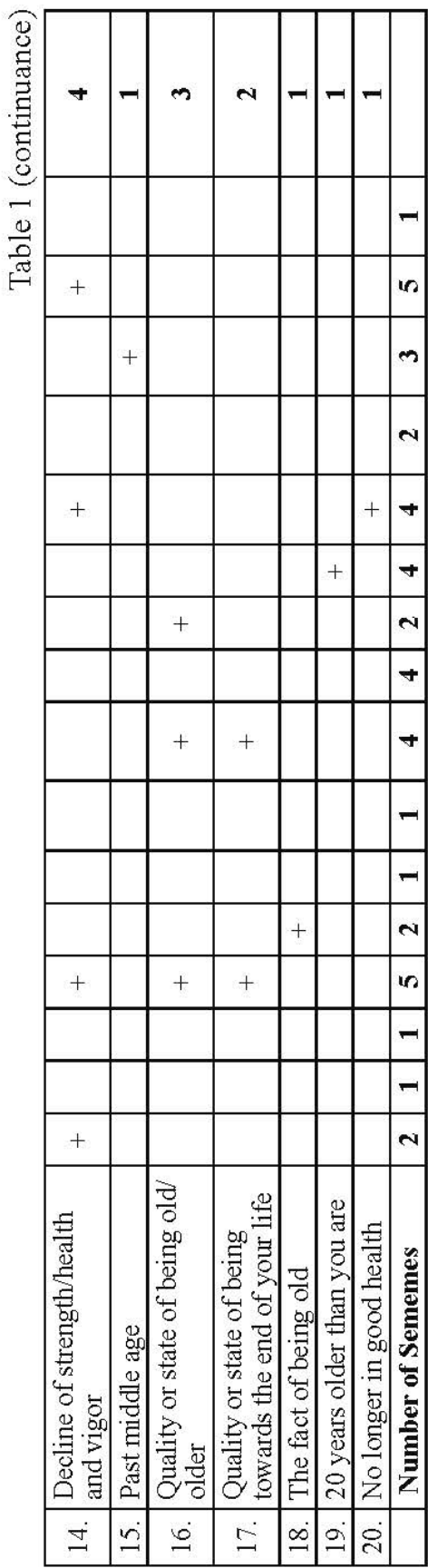

These diverse lexico-semantic variants contain very interesting definitional features. Firstly, it can be assumed that OLD AGE is categorized as a stage, time or part in life. Furthermore, the definitional features [time], [stage] and [part] are specified by providing semantic distinctions: [final stage], [part after your prime], [ideal time] etc. Thus, the conceptualization of OLD AGE in English results in presenting it as a final stage of life, following the middle age period and the person in this period becomes old or/and with serious health problems.

The list of dictionary definitions suggests that not all the components of meaning are represented in certain dictionaries. It is observed that a greater number of meanings are found only in 2 out of 16 lexicographical sources, namely in sources IV Collin's English Dictionary and XV Your Dictionary, where the lexeme old age is represented with the help of 5 sememes. The results of the definitional analysis illustrate that in 5 dictionaries, such as VIII - CoBuild, IX - Free Dictionary, XI - Urban Dictionary, XII - Wordsmyth Dictionary Online the concept OLD AGE is verbalized by means of 4 sememes. Three sememes can be identified in the structurer of the noun old age in source XIV - Word Net Dictionary Online. Other four dictionaries represent 2 lexical-semantic variants each: I- Webster's New World Dictionary, V - Merriam Webster's Online Dictionary, X - Oxford English Living Dictionary, XIII - Ultralingua. 
Similarly, only 5 sources, such as II - Oxford Advanced Learner's Dictionary, III - Cambridge Dictionary Online, VI - Dictionary. Com, VII MacMillan Online Dictionary, XVI - Longman Dictionary of Contemporary English disclose only one meaning of the lexeme old age.

The results of the preliminary analysis might serve as a basis for further subdivision of the nuclear zone of the nominative field into 2 main segments: 1) Period and 2) State.

Firstly, the segment Period implies that OLD AGE is said to be a period of human age, one of the life stages, usually the final one, the end of human life. Pimenova adds that "the conceptual structure is made up of primary (or basic) and secondary features. Basic features are verbalized in dictionary definitions of the corresponding lexeme serving as the concept's name in the form of its semantic components - semes and sememes”. In Lipka's words, the seme is a semantic feature and the sememe is defined as a "complex or configuration of semes, which corresponds to a single sense of a lexeme" 25 .

However, it is the definitional feature that could be regarded as the smallest component of the nominative field that is represented in lexicographical sources. ${ }^{26}$ Accordingly, dictionary definitions of the lexeme old age prove to comprise such common definitional features, as [period], [time], [years], [stage], [part]. For instance:

1) The definitional feature [period] is observed in the following sememes - [the period in a person's life when one is old], [the period of your years towards the end of your life], [the last period of human life], [the period (stage) after 65];

2) The definitional feature [time] is represented in the sememes - [the time of life when one is old], [the (a) late (latter) time of life], [the ideal time when you don't feel inhibited to say something embarrassing or outrageous because your days are numbered];

3) Another definitional feature [part] is found in the sememes [the part of your life when you are old], [the later (latter) part of (normal) life], [the part after your prime];

4) The definitional feature [years] is observed in the dictionary entry [advanced/-ing years] to talk about this period of human life;

5) Finally, the definitional feature [stage] is highlighted when old age is defined as [the final stage of human life], [the last stage when you stop lying about your age and start dragging about it], [the stage after 65].

${ }^{25}$ Lipka L. English Lexicology: Lexical Structure, Word Semantics and Word-Formation. Gunter Narr Verlag, 2002.

${ }^{26}$ Колегаєва I.М. Конструювання номінативного поля концепту: етапи та одиниці // Записки з романо-германської філології. 2018. № 1(40). С. 122-123. 
In this research, we hypothise that the main feature - [period] - is further specified and clarified in the definitions of every sememe, thus adding to the nuclear zone of the concept OLD AGE. The seme Period is complemented with the qualificational semes that explain the nature of this period. Consequently, it is [last period], [end of life], [final stage], [advanced years], [last stage], [late (latter) time]. These semes (in italics) describe OLD AGE as the end of human life, its last or late/later period. Relative qualificational semes chronologically refer the period to a certain point in time: e.g., the period when you reach 65 [the period after 65]. Conversly, the feature [past middle age] defines it as following the middle age period without mentioning the exact chronological age.

Relative qualificational feature [part after prime] leads to understanding old age as the period of decline which comes after the period of the greatest strength or vigour, consequently it helps to reveal negative evaluative component in the semantic structure of the lexeme old age.

There is also a unique definition of old age in Urban Dictionary [20 years older than you are]. This sememe defines old age by applying a relative feature [20 years older] and comparing this period with the speaker's age. This leads to understanding that anyone, who is 20 years older than you are, is believed to be old. Due to this fact, the beginning of old age is not linked to a chronological age, but is rather floating, when "being aged" means "being older than yourself". Such approaches are especially typical of the younger generation and might represent some of the social ageist attitudes. Moreover, the example in Urban Dictionary is used to explain that old age is not fixed to a certain age, not "demarcated as the period of life occurring after sixties or seventies" ${ }^{27}$, on the contrary, it is a flexible notion: e.g. "When you are 10, 30 is old. When you reach 30,50 seems old. When you reach 50,70 seems old and so on. So it is a shifting scale where nobody ever thinks they are old"28.

Also, the interpretation of dictionary definitions discloses one more characteristic feature of OLD AGE when it can be treated as an ideal time. The definitional feature [ideal time] is used to conceptualize the period when you are free to express your feelings and emotions. Sememes 3 and 13 (see Table 1), in a rather extravagant way, define the lexeme old age, adding to its evaluative component of meaning, because it is a period which makes you free in your expressions, no more limits and taboos [stop lying about your age] and one can be really abusive - [don't feel inhibited to say something embarrassing]. And the reason for this is that

\footnotetext{
${ }^{27}$ New definition for old age. Science Daily. URL: https://www.sciencedaily.com.

${ }^{28}$ Urban Dictionary. https://www.urbandictionary.com.
} 
[your days are numbered] and you no longer depend on or care about social norms of behaviour accepted in your community.

The nucleus of the concept OLD AGE includes another segment State, with the definitional features [state], [quality] and [fact]:

1) The [state] proper and [quality] - [quality or state of being old/ older], [quality or state of being towards the end of your life];

2) Existential feature [fact] - [the fact of being old];

3) The state of having health problems and related issues - [no longer in good health], [decline of strength/health and vigor].

The sememes mentioned above provide the definitions of old age by using the adjective old - the state, quality, fact of [being old/older]. As Evans (2015) suggests, the grammatical distinction between the adjective and noun appears to relate to a semantic distinction between the notion of property versus thing. ${ }^{29}$ The words old and old age, while indexing the same (or similar) perceptual state, also encode schematic concepts: property versus thing. Thus, old age might be regarded as the property of being old. This contributes to disclosing the notional component of OLD AGE concept by the stylistically neutral lexical unit old as a constituent of its nuclear zone (which could be the object of further research).

Another conceptual feature in this segment is represented by the sememe [decline of strength/health and vigor], specifying old age as a state of poor health because of being old. This semantic component of meaning proves the dominant ageist stereotype when being old equals to being seriously ill, when ageing is usually viewed as a process of inevitable decline (e.g., Gual, 2015) ${ }^{30}$. The analysis of the dictionary definitions demonstrates that old age is regarded as the state when your health is no longer strong enough, you are feeble and in poor condition.

\section{The Synonyms to the Noun Old Age: Cognitive-Semantic Analysis}

A very important stage in our research is cognitive-semantic analysis of synonyms to the key lexeme, which are subdivided into the corresponding synonymic groups: the temporal group Life Period, representing old age as a life stage/period, and the classificational group State, expressing a qualitative feature.

${ }^{29}$ Evans V. What's in a concept? Analog versus parametric concepts in LCCM Theory. // The Conceptual Mind: New Directions in the Study of Concepts, MIT Press, 2015. P. 271.

${ }^{30}$ Gual N. Ambivalent Pathways of Progress and Decline: The Representation of Aging and Old Age in Joanna McClelland Glass's Drama. // Theatre Research in Canada / Recherches théâtrales au Canada, 2015. 36 (1). 
The first synonymic group Life Period characterizes old age as a period in human life. The analysis of individual dictionary definitions of the synonyms helps to define their common definitional features [period, years, time, stage, age], which are further specified. These verbal units can be grouped as to their semantic components:

1) The first group encodes old age as the period when one is old or elderly: e.g., advanced /advancing years [the period of being elderly], agedness [the period of advanced years], ageing [growing older], Anno Domini [advancing old age] informal, autumn of one's life [the period of being elderly, old age], elderliness [the stage of life well past middle age], evening of one's life [the period of being elderly], oldness [period of being elderly].

These synonyms provide a neutral characteristic of old age, describing it as a life period with the generalized meaning when a person is old, elderly or in advanced years. The analysis of these sememes helps to highlight the definitional features [old], [elderly], [past middle age], [advanced years], [advancing].

2) The second group represents OLD AGE as the final stage of life, the last years of age: age [a late time of life, the latter years of life], decline [the last part of life], declining years [the last years of someone's life], eld ${ }_{\text {archaic }}$ [a late time of life], extremity [the end of life, dying] archaic, Fourth Age [starting at about age 80 or 85, includes the last years of adulthood], geezerhood [a late time of life], senectitude [the final stage of normal life span], twilight/twilight years [the last years of life], winter of one's life, years [a late time].

The analysis of dictionary definitions of the synonymic units in this group reveals a negative-evaluative semantic component of their specificational definitional features - [the final stage], [the last years], [the last part of life], [a late time], [the end of life, dying]. The semes final, last, late, end provide the verbalization of what is labelled as "decline ideology", ${ }^{31}$ i.e. the prevailing social attitude to old age and ageing as the last period, the last stage in the lifespan when old age is considered to be a problem causing decline. Furthermore, the lexeme extremity, with archaic stylistic connotation, encodes the meaning of dying, thus representing a gloomy picture of old age that inevitably leads to death. The lexeme Fourth Age defines old age chronologically as the period starting at about age 80 or 85 . Sociologists state that " $<\ldots>$ the fourth age embodies all the fears of old age; it brings fragility, helplessness and loss of autonomy”, ${ }^{32}$.

\footnotetext{
${ }^{31}$ Gullette Margaret M. Aged By Culture. Chicago: University of Chicago Press, 2004. P. 7.

${ }^{32}$ Petrová Kafková M. The „Real“ Old Age and the Transition between the Third and Fourth Age / Sociológia 48, 2016. № 6 . P.623.
}

64 
For active people in the third age, fourth agers represent „the others“ ${ }^{33}$. Moreover, they suggest a dual view of old age, discriminating between the concepts of the young-old and old-old, e.g. Neugarten (1974). ${ }^{34}$ However, it is Laslett who introduces the terms "third and fourth age" and characterizes the fourth age as a period of final infirmity, decrepitude and death $^{35}$. Thus, the sememe [starting at about age 80 or 85 , includes the last years of adulthood] indexes not only the chronological marker $80+$, but also the evaluative connotational feature of decline.

The lexeme senectitude originates from Latin senect( $\bar{u} s)$ meaning “old age" and is first recorded in English in the period 1790-1800. The dictionary definition shows the specificational definitional feature [the final/last stage].

Another group of synonyms describes OLD AGE as the period of delight, happines and enjoyment of life: e.g., green old age [a period when you might not be able to do all the things you used to do, as well as you used to do them, but there are also likely to be fewer demands on you and less stress], Indian Summer [the final period of a person's life regarded as tranquil, serene], [a pleasant or successful time nearly at the end of your life].

Firstly, we can observe the presence of the hyperseme period in these sememes together with its equonymic seme time. Also, these semes are specified with the definional features [tranquil, serene], [pleasant or successful], [fewer demands on you and less stress], which help to reveal positive evaluative component in the semantic structure of the nominative units green old age and Indian Summer. This goes in line with "the narrative of success ignoring the physical dimensions of aging” (Gual 2005) and the notion of "successful aging" that combines life satisfaction, happiness, good health and longevity.

Moreover, a number of synonyms describe old age chronologically by decades: sixties [the period when a person is aged from 60 to 69], seventies [the period when a person is aged from 70 to 79], eighties [the period when a person is aged from 80 to 89], nineties [the period when a person is aged from 90 to 99]. The seme period is specified in each of these sememes by indicating the corresponding decade [from 60 to 69], [from 70 to 79], [from 80 to 89] and [from 90 to 99].

${ }^{33}$ Gilleard C., Higgs P. Cultures of Ageing: Self, Citizen, and the Body. Essen: Perason Education, 2000.

${ }^{34}$ Neugarten B. L. Age Groups in American Society and the Rise of the Young-Old. // The ANNALS of the American Academy of Political and Social Science, 415 (1), 1974. P. 187-198.

${ }^{35}$ Laslett P. A Fresh Map of Life: The Emergence of the Third Age. Harvard University Press, 1991. 
A special attention should be paid to stylistically neutral lexemes of Latin origin representing OLD AGE chronologically: e.g., sexagenarianism [the state of being sexagenarian], septuagenarians [the state of being septuagenarian], octogenarianism [the state of being octogenarian], nonagenarianism [the state of being nonagenarian]. Further definitional analysis reveals the onomasiological basis of these lexical units, used to denominate a state of a person whose age is in the sixties (sexagenarian - from Latin sexagenarius of or containing sixty, sixty years old), seventies (septuagenarian - from Latin septuagenarius of or containing seventy, seventy years old), eighties (octogenarian - from Latin octogenarius containing eighty), nineties (nonagenarian - from Latin nonagenarius containing ninety).

One of the prevailing social perceptions of old age and older adults is that they are retired and receive pensions from the government. This meaning is encoded in the following synonymic units: e.g., golden years [the time of life retirement from active work], [the years after the retirement], pension (pensionable) age, retirement [the years after retirement]. The semes time, years are specified as the the time of [retirement from active work], [after retirement] with the hyponymic seme retirement encoding the meaning of the period when a person stops working. The definitions of the synonym golden years [the term used by old folks who are too attached to their youth to admit that they are in fact: old, senile, and wrinkly], [the ages during retirement toward the end of one's life, but enough to still enjoy the remainder; typically 65 and up] in the entries of Urban Dictionary index old age, pointing to its positive and negative aspects simultaneously. On the one hand, the definitional features [attached to their youth], [still enjoy] encode the semantic component of enjoyment with the verb enjoy and the period when a person still feels young by using the antonym youth. On the other hand, the definitional features [the ages during retirement] [old, senile, and wrinkly], [toward the end of one's life] add to the negative evaluation of old age. Also, the definitional feature [typically 65 and up] defines the chronological limits of old age.

Lexical units within the synonymic group State represent old age in different ways.

Firstly, it is defined as the state of being old: e.g., age [the state of being old or becoming old], advanced age [the age of someone who is old], antiquity [great age], elderhood [the state, quality, or condition of being an elder], geromorphism [a condition of appearing prematurely old or aged], grand old age [the state when a person is very old], senescence [the state of being old, aged]. As a result of the definitional analysis the seme state with its equonyms quality, age, or condition is revealed in 66 
every sememe, and it is specified by means of hyposemes old, elder, aged. Thus, all these synonyms index old age as the state when you are old/aged/elder. The definitions of the nominative units antiquity, geromorphism, grand old age include the evaluative definitional features [prematurely old or aged], [very old], [great age] expressing the intensifying connotational meaning.

A great number of synonyms define old age as a state of being ill: Alzheimer's disease [showing poor mental health; a loss of mental faculties because of old age], [deterioration of mental faculties], anecdotage [old age, especially in someone who is inclined to be garrulous], [senility, as characterized by the telling of rambling anecdotes], anility [the condition of behaving like an old woman, used especially of men], [the quality resembling a doddering old woman; old-womanishness; dotage], caudicity [senility - physical and mental decline associated with old age], decay [deterioration], dementia [a state of serious mental deterioration], dotage [mental infirmity as a consequence of old age shown by foolish infatuations]; [feeble and childish state due to old age]; [senile decay marked by decline of mental poise and alertness], infirmity, senility [the quality of being senile, i.e. showing poor mental ability because of old age]; [confused, unable to look after themselves, no longer remember things], second childhood [when someone starts to behave like a child, esp. because of mental weakness caused by old age], sundowning [agitation or anxiety at night by elderly patients].

All these sememes are characterized by the presence of the hyperseme state or its synonyms condition and quality that are specified with the qualificational features [poor mental health], [a loss of mental faculties], [deterioration of mental faculties], [mental infirmity], [being senile], [mental weakness], [no longer remember things], [poor mental ability], [mental decline], [decline of mental poise and alertness]. These semantic components encode the social stereotypes and focus on age related diseases, primarily mental decline, contributing to a negative ageist view of old age as a state of deterioration and decadence. Negative components of meaning in such definitional features [confused, unable to look after themselves], [foolish infatuations], [doddering old woman] are quite obvious and these units provide the verbalization of the negative perception of old age. Two synonymic units, second childhood and dotage, compare old age with another life stage, the period of childhood, by providing the definitional features [childish state], [behave like a child]. This also helps to disclose another conceptual feature of old age, such as dependence, similar to children who usually depend on their parents or guardians. The lexical unit anecdotage is defined as [old age, especially 
in someone who is inclined to be garrulous], [senility, as characterized by the telling of rambling anecdotes] with the specificational features [garrulous] and [the telling of rambling anecdotes] which at the second level of definitional analysis are defined as [excessively talkative, especially on trivial matters] and rambling [lengthy and confused or inconsequential]. Thus, anecdotage is used to index that constituent part of the concept OLD AGE which labels it derogatorily.

Also, one of the synonyms coined not long ago (the earliest mention in 1986) ${ }^{36}$ is sundowning which refers to the state of anxiety and agitation or nervous excitement and is said to be the symptom of Alzheimer's disease and other forms of dementia. Merriam-Webster's Dictionary gives the following medical definition [a state of increased agitation, confusion, disorientation, and anxiety that typically occurs in the late afternoon or evening in some individuals affected with dementia] ${ }^{37}$. The specificational features explicitly index old age as the state of serious illness, with the semes confusion, disorientation and anxiety adding to its negative psychological and emotional characteristics.

The biomedicalization of old age has led to its categorization as the state of weakness. The following goup of synonyms are united on the basis of this specificational feature: decline [smb's old and becoming weaker], decreptitude [the state of being old and no longer in good condition or health $]_{\text {formal }}$, feebleness [the state of being physically and mentally weak], infirmity [poor or deteriorated vitality because of old age], sarcopenia [the age related loss of muscle mass and strength], weakness [the state or condition of lacking strength]. The definitional features [becoming weaker], [no longer in good condition], [being physically weak], [poor or deteriorated vitality], [lacking strength], [loss of strength] altogether verbalize the conceptual feature of weakness as a state because of old age.

The sememes of another group of synonyms in their unity represent old age as associated with changes in appearance, the bodily marker of ageing, such as greying: e.g., grey hairs [a lightening of the hair caused by aging, old age], greying [the state or process of becoming old], hoariness [the state of being grey or white with age]; [the state of being white or whitish]. The examples above show that their common specificational definitional features is [grey] with its hyponyms [lighting/white/whitish].

However, the analysis proves that some of the synonyms have sememes that represent OLD AGE positively as longevity, experience, possibility for self-development, respect and active lifestyle. Together they

\footnotetext{
${ }^{36}$ Word Spy. https://www.wordspy.com/index.php?word=sundowning).

${ }^{37}$ Merriam Webster's Dictionary. https://www.merriam-webster.com\%2Fmedical\%2Fsundowning.
} 
constitute the conceptual domain Experience/Maturity with the definitional features - [experience], [maturity], [longevity], [being energetic/in good health]: e,g., experience [knowledge or skill in a particular job or activity, which you have gained because you have done that job or activity for a long time], longevity [advancement, continuence]; [living for a long time], maturity, matureness [state of being mature]; [full development], a ripe old age [the condition of being very old, used to talk about someone who has a long healthy life], seniority [the state of being senior; priority of birth; superior age], sprightliness [the quality of being energetic and in good health, especially when you are old],Third Age [old age with opportunities to travel and further education].

\section{CONCLUSIONS}

This research follows the cognitive-semantic paradigm which has already become traditional in defining the notional content of verbalized concepts. The analysis of the dictionary definitions demonstrates that the nucleus of the nominative field of the concept OLD AGE is made up of twenty sememes. The preliminary analysis might serve as a basis for further subdivision of the nuclear zone into two main segments that can be named as Period and State. Accordingly, dictionary definitions of the lexeme old age prove to display such common definitional features, as [period], [time], [years], [stage], [part] within the segment Period and [state], [quality], [fact] + being old/older, and [decline] + because of old age] in the segment State.

The results described are fairly general, however they show that OLD AGE in English is constructed in different ways: chronologically; as a social construct; the age of longevity, wisdom and life satisfaction, confirming the theory of "successful ageing"; adopting a purely biomedical approach and indexing OLD AGE as a period of decline, mental and physical weakness; and also as a retirement period.

Cognitive-semantic analysis of synonyms, making up the medial zone of the nominative field, results in dividing them into similar synonymic groups: the temporal group Life Period, representing OLD AGE as a life stage/period, and the classificational group State, expressing a qualitative feature.

This research provides implications for further study of old age and ageing individuals in different types of discourses. This can help not only to specify the notion of old age as a lingual-cultural phenomenon, but also provide criteria for defining the conceptual model of OLD AGE in English. 


\section{SUMMARY}

The present research deals with the study of the concept OLD AGE in English with the focus on the analysis of the lexical unit old age used as its name. The topicality of such works is quite obvious, since the concept has recently become an object of a multidimensional linguistic study. Research material has been selected from present-day lexicographical sources with the analysis of dictionary definitions, as well as componential analysis. Furthemore, one issue of this study is the cognitive-semantic analysis of synonyms to the key lexeme old age. The research findings provide implications for further studies of this concept in different types of discourse that will contribute to a deeper understanding of old age as a lingual-cultural phenomenon and provide criteria for defining the conceptual model of the concept OLD AGE.

\section{REFERENCES}

1. Evans V. Conceptual vs. Inter-lexical polysemy. An LCCM Theory Approach.// Language Learning, Discourse and Cognition: Studies in the tradition of Andrea Tyler. Eds. Pickering L., Evans V. John Benjamins Publishing House, 2018. P. 159-190.

2. Evans V. What's in a concept? Analog versus parametric concepts in LCCM Theory. // The Conceptual Mind: New Directions in the Study of Concepts, MIT Press, 2015. P. 251-290.

3. Evans V., Green M. Introduction to Cognitive Linguistics. / V. Evans, M. Green. N.Y.: Routledge, 2015.

4. Gilleard C., Higgs P. Cultures of Ageing: Self, Citizen, and the Body. Essen: Perason Education, 2000.

5. Gual N. Ambivalent Pathways of Progress and Decline: The Representation of Aging and Old Age in Joanna McClelland Glass's Drama. // Theatre Research in Canada / Recherches théâtrales au Canada, 2015. 36 (1).

6. Gullette Margaret M. Aged By Culture. Chicago: University of Chicago Press, 2004.

7. Langacker R. Foundations of Cognitive Grammar. Volume I. Stanford: Stanford University Press, 1987.

8. Laslett P. A Fresh Map of Life: The Emergence of the Third Age. Harvard University Press, 1991.

9. Lipka L., English Lexicology: Lexical Structure, Word Semantics and Word-Formation. Gunter Narr Verlag, 2002.

10. Neugarten B. L. Age Groups in American Society and the Rise of the Young-Old. // The ANNALS of the American Academy of Political and Social Science, 415 (1), 1974. P. 187-198. 
11. New definition for old age. Science Daily. URL: https://www.sciencedaily.com.

12. Petrová Kafková M. The „Real“ Old Age and the Transition between the Third and Fourth Age / Sociológia 48, 2016, № 6. P. 622-640.

13. Rosch E. Natural categories / E. Rosch // Cognitive Psychology. Elsevier, 1973. - V. 7. - P. 328-350.

14. Алефиренко Н. Ф. Современные проблемы науки о языке: Учебное пособие. М. : Флинта: Наука, 2005. 416 с.

15. Бабушкин А.П. Концепты разных типов в лексике и фразеологии и методика их выявления. // Методологические проблемы когнитивной лингвистики. Воронеж: Изд-во Воронеж, гос. ун-та, 2001. C. 52-57.

16. Єсипенко Н. Г. Текстові концепти та методи їх аналізу. // Вісник Волинського національного університету імені Л. Українки. Мовознавство. Луцьк : ВНУ, 2009. Вип. 5. С. 253-257.

17. Колегаєва I. М. Конструювання номінативного поля концепту: етапи та одиниці // Записки з романо-германської філології. 2018. № 1(40). С. 121-127.

18. Кубрякова Е. С. Язык и знание: на пути получения знаний о языке : части речи с когнитивной точки зрения. Роль языка в осознании мира : [монографія]. - М. : Язык славянской культуры. 2004. $555 \mathrm{c}$.

19. Кубрякова Е. С. К определению понятия имиджа / Е. С. Кубрякова // Вопросы когнитивной лингвистики . 2008. № 1. С. 5-12.

20. Левицкий В.В. Семасиология. Винница: Нова книга. 2006. 512 c.

21. Никитин М. В. Курс лингвистической семантики. СанктПетербург: Научный центр проблем диалога, 1996. 760 с.

22. Пименова М. В. Предисловие. // Введение в когнитивную лингвистику. Кемерово, 2004. 208 с.

23. Попова 3. Д. Когнитивная лингвистика / 3. Д. Попова, И. А. Стернин. М. : АСТ : Восток-Запад, 2007. 314 с.

24. Селіванова О.О. Сучасна лінгвістика: термінологічна енциклопедія. Полтава : Довкілля-К, 2006. 716 с.

25. Смаглій В. М. Ядро номінативного поля концепту LANGUAGE. Вчені записки ТНУ імені В. І. Вернадського. Серія: Філологія. Соціальні комунікації. Том 30 (69). № 2 Ч. 1. 2019. С. 119-123.

26. Стернин И. А. Методика исследования структуры концепта // Методологические проблеми когнитивной лингвистики: научное издание / Под редакцией И. А. Стернина. Воронежский государственный университет, 2001. С. 58-65. 
27. Стернин И. А. Методы описания семантики слова. Ярославль: Истоки, 2013.

28. Чаграк Н. І. Соціальні теорії старіння і старості у контексті освітньої геронтології. Теоретичні питання культури, освіти та виховання : зб. наук. праць Київського національного лінгвістичного університету. 2015. № 52. С. 154-160.

\section{SOURCE MATERIAL}

1. Cambridge Dictionary. https://www.dictionary.cambridge.org

2. Collins English Dictionary. Co Build. https://www.collinsdictionary.com

3. Dictionary.com. https://www.dictionary.com

4. Longman Dictionary of Contemporary English. https://www.ldoceonline.com

5. Macmillan Dictionary. https://www.macmillandictionary.com

6. Merriam Websters Dictionary. https://www.merriam-webster.com

7. Oxford English Living Dictionary.

8. Oxford Advanced Learner's Dictionary.

9. https://www.oxfordlearnersdictionaries.com

10. The Free Dictionary. https://www.thefreedictionary.com

11. Ultralingua https://www.ultralingua-dictionary.e.softonic.com

12. Urban Dictionary. https://www.urbandictionary.com

13. Webster's New World Dictionary of American English / Ed. V. Neufeldt. N.Y.: Prentice Hall, 1994. 1570 p.

14. Word Net Dictionary Online. https://www. wordnet.princeton.edu 15. Word Spy. https://www.wordspy.com

16. Wordsmyth Dictionary Online. https://www.wordsmyth.net

Information about the author: Holyk S. V., Candidate of Philological Sciences, Associate Professor, Head of the English Philology Department of the State University "Uzhhorod National University” 14, Universytetska str., Uzhhorod, 88000, Ukraine 